\title{
Dietary L-Carnitine prevents histopathological changes in Tilapia (Oreochromis niloticus) exposed to Cylindrospermopsin
}

Remedios Guzmán-Guillén ${ }^{\mathrm{a}^{*}}$, Ana I. Prieto Ortega ${ }^{\mathrm{a}}$, Rosario Moyano ${ }^{\mathrm{b}}$, Alfonso Blanco ${ }^{\mathrm{c}}$, Vitor Vasconcelos ${ }^{\mathrm{d}, \mathrm{e}}$, Ana M. Cameán ${ }^{\mathrm{a}}$

a Area of Toxicology. Faculty of Pharmacy. University of Sevilla. C/Profesor García González 2, 41012 Sevilla. Spain.

b Department of Pharmacology, Toxicology and Legal and Forensic Medicine, University of Córdoba. Campus de Rabanales Carretera Madrid-Cádiz s/n, 14071 Córdoba. Spain.

${ }^{c}$ Department of Anatomy and Comparative Pathology and Anatomy, University of Córdoba. Campus de Rabanales Carretera Madrid- Cádiz s/n, 14071 Córdoba. Spain.

${ }^{d}$ Interdisciplinary Centre of Marine and Environmental Research (CIIMAR/CIMAR), Porto 4050-123, Portugal.

e Department of Biology, Faculty of Sciences of the University of Porto, Porto 4169007, Portugal.

\section{*Corresponding author:}

Remedios Guzmán Guillén

Area of Toxicology. Faculty of Pharmacy. University of Sevilla

C/ Profesor García González 2, 41012 Sevilla, Spain.

e-mail address: rguzman1@us.es

Tel: +34954 556762

Fax: +34 954233765

Running title: L-carnitine prevents CYN-induced histopathological changes in Tilapia 


\begin{abstract}
Cylindrospermopsin (CYN) is a cytotoxin highly water-soluble which is easily taken up by several aquatic organisms. CYN acts as a potent protein and glutathione synthesis inhibitor, as well as inducing genotoxicity, oxidative stress and histopathological alterations. This is the first study reporting the protective effect of a Lcarnitine (LC) pretreatment (400 or $880 \mathrm{mg} \mathrm{LC} / \mathrm{kg}$ bw fish/day, for 21 days) on the histopathological alterations induced by pure CYN or Aphanizomenon ovalisporum lyophilized cells (400 $\mu \mathrm{g} \mathrm{CYN/kg} \mathrm{bw} \mathrm{fish)} \mathrm{in} \mathrm{liver,} \mathrm{kidney,} \mathrm{heart,} \mathrm{intestines} \mathrm{and} \mathrm{gills} \mathrm{of}$ tilapia (Oreochromis niloticus) acutely exposed to the toxin by oral route. The main histopathological changes induced by CYN were disorganized parenchyma with presence of glycogen and lipids in the cytoplasm (liver), glomerulonephritis, glomerular atrophy and dilatation of Bowman's capsule (kidney), myofibrolysis, loss of myofibrils, with edema and haemorrhage (heart), intestinal villi with necrotic enterocytes and partial loss of microvilli (gastrointestinal tract), and hyperemia and haemorrhage (gills). L-carnitine pretreatment was able to totally prevent those $\mathrm{CYN}$-induced alterations from $400 \mathrm{mg} \mathrm{LC} / \mathrm{kg}$ bw fish/day in almost all organs, except in the heart, where $880 \mathrm{mg}$ $\mathrm{LC} / \mathrm{kg}$ bw fish/day were needed. In addition, the morphometric study indicated that LC managed to recover totally the affectation in the cross sections of the proximal and distal convoluted tubules in CYN-exposed fish.
\end{abstract}

Keywords: Cylindrospermopsin, Aphanizomenon ovalisporum, L-carnitine, Histopathology, Tilapia. 


\section{Introduction}

The eutrophication of lakes and reservoirs leads to water blooms of cyanobacteria in many countries throughout the world, decreasing the water quality by the release of off flavours, water discoloration and accumulation of surface scums (Ibelings and Chorus, 2007). Equally important is the ability of some bloom-forming species of cyanobacteria to produce secondary metabolites, namely the cyanotoxins (Moreira et al., 2012). Cylindrospermopsin (CYN) is recognized as one of the most globally important freshwater algal toxins. Structurally, CYN is a tricyclic guanidine moiety combined with hydroxymethyluracil first isolated and identified in 1992 (Ohtani et al., 1992) and highly soluble in water (Sivonen and Jones, 1999). Four naturally occurring analogues of CYN have been also identified: 7-epicylindrospermopsin (7-EpiCYN), deoxy-cylindrospermopsin (7-deoxy-CYN) (Kinnear, 2010), 7-deoxy-desulfocylindrospermopsin and 7-deoxy-desulfo-12-acetylcylindrospermopsin (Wimmer et al., 2014). The ever-expanding distribution of CYN producers into temperate zones is heightening concern that this toxin will represent serious environmental and human health risks across many countries (Kinnear, 2010).

Several authors have showed that CYN causes damages in different organs (liver, kidney, lungs, thymus, spleen, adrenal glands, intestinal tract, the immune system and heart) in mammals, consistent with the concept of a more general cytotoxicity and its action as an inhibitor of protein and glutathione synthesis (Runnegar et al., 1994; Falconer et al., 1999; Hawkins et al., 1985; Humpage et al., 2000; Terao et al., 1994), as well as genotoxicity (Humpage, 2008; Bazin et al., 2010). Experiments from our laboratory have demonstrated the important role of oxidative stress in the mechanism of CYN-toxic action in vivo (Gutierrez-Praena et al., 2011a; Puerto et al., 2011; GuzmánGuillén et al., 2013a) and in vitro in different human and fish cell lines (GutiérrezPraena et al., 2011b; 2012a,b). Moreover, different studies have demonstrated that CYN can produce histopathological changes in several tissues of tilapia (Oreochromis niloticus) acutely exposed to pure CYN orally (Puerto et al., 2014) or by intraperitoneal injection (Gutiérrez-Praena et al., 2012c), or subchronically exposed to cyanobacterial cells containing CYN by immersion (Guzmán-Guillén et al., 2015a).

Furthermore, morphometric studies concerning CYN toxicity in several organs of tilapia have demonstrated changes in the average nuclear diameter of hepatocytes, as 
well as in the cardiac fibers and capillaries diameters in the heart (Gutiérrez-Praena et al., 2012c; Guzmán-Guillén et al., 2015a,b). However, contradictory results have been described for the kidney, with decreased cross sections of proximal and distal convoluted tubules after a 5-day exposure to pure CYN (Gutiérrez-Praena et al., 2012c), whereas increases were found after 24 h-exposure to pure CYN (Guzmán-Guillén et al., 2015b) and after 7-days exposure to cyanobacterial cells containing CYN and deoxyCYN (Guzmán-Guillén et al., 2015a).

Research into CYN has been performed with pure standard toxin, extracted toxin and cyanobacterial cells containing CYN. Several studies suggest that cell extracts hence field populations of CYN-producing blooms - are likely to contain one or more bioactive compounds other than CYN, hence increasing the risk of toxic effects (Falconer et al., 1999; Hawkins et al., 1997; Norris et al., 1999; Seifert, 2007). In tilapia, exposure to cyanobacterial cells (A. ovalisporum) containing CYN and deoxyCYN induced higher effects on several oxidative stress biomarkers in comparison to pure CYN (Gutierrez-Praena et al., 2012d), but possible differences concerning histopathological changes have not been studied yet.

The protective effects of different antioxidants against the toxic action of cyanobacterial toxins, mainly Microcystins (MCs) and CYN, in aquatic organisms has been previously reported. In some previous papers we showed that selenium (Se), vitamin $\mathrm{E}$ and $\mathrm{N}$-actylcysteine (NAC) could restore tissue redox status and pathological alterations in fish following exposure to toxic cyanobacterial cells containing MCs (Atencio et al., 2009; Prieto et al., 2008, 2009; Puerto et al., 2009, 2010). Regarding CYN, to the extent of our knowledge, there are currently three substances that have demonstrated prevention of oxidative stress and/or histopathological lesions in fish exposed to this toxin: NAC (Gutiérrez-Praena et al., 2012d; 2014), vitamin E (GuzmánGuillén et al., 2015b,c) and L-carnitine (LC) only against oxidative stress (GuzmánGuillén et al., 2013b).

L-carnitine ( $\beta$-hydroxy- $\gamma$-N-trimethyl ammonium-butyrate; LC) is a watersoluble quaternary amine synthesized from protein-bound lysine and methionine, with the assistance of vitamin $\mathrm{C}$ and other secondary compounds produced in animal bodies (Rebouche, 1991). LC plays an important role in fatty acid metabolism, as its major function is the transport of long-chain fatty acids into mitochondria for oxidation, 
particularly in the heart and skeletal muscles (Bueno et al., 2005). LC also serves a protective role against reactive oxygen species (ROS) by exerting antioxidant properties (Derin et al., 2004; Gómez-Amores et al., 2007; Guzmán-Guillén et al., 2013b). Histopathological studies suggest that LC might have a protective effect against ischemia-reperfusion (IR) injury in rat liver (Canbaz et al., 2007), and against myocardium pathological alterations in dogs (Folts et al., 1978; Keene et al., 1991). Previous work has shown the beneficial effects of LC on fish and crustacean growth and on feed conversion in marine and freshwater species (Becker et al., 1995; Chatzifotis et al., 1995; Rodehutscord, 1995; Santulli and D'Amelio, 1986; Torreele et al., 1993; Yang et al., 2012). Furthermore, LC protects fish against high levels of ammonia and xenobiotics (Santulli and D'Amelio, 1986, Tremblay and Bradley, 1992; Schreiber et al., 1997), and alleviates the stress related to extreme water temperature changes (Harpaz et al., 1999). Specifically in tilapia fish, Jayaprakas et al. (1996) reported that LC supplementation (900 mg LC/kg diet) had a positive effect on their growth and reproductive performance, whereas Schlechtriem et al. (2004) showed that LC treatments had no effect on the growth or survival of hybrid tilapia, although it offered better resistance to xenobiotics. LC could also stimulate physiological regeneration and prevent pathological alterations of epithelial layers in gills and skin of guppy fish (Schreiber et al., 1997).

The aim of the present study was to evaluate the effectiveness of a LC pretreatment (400 or $880 \mathrm{mg} \mathrm{LC} / \mathrm{kg}$ body weight -bw- fish/day, for 21 days) on the pathological and ultrastructural changes induced by pure CYN or by A. ovalisporum cells (containing CYN and deoxy-CYN) in liver, kidney, heart, intestines and gills of tilapia (O. niloticus) acutely exposed to the toxin by oral route. To the extent of our knowledge, this is the first study concerning the prevention of these alterations by LC in fish intoxicated with CYN.

\section{Materials and Methods}

\subsection{Chemicals}

Pure CYN (purity > 95\%) was supplied by Alexis Corporation (Lausen, Switzerland). LC was provided by Fragon Ibérica (Barcelona, España 32183-12). Chemicals for the different assays were provided by Sigma-Aldrich and VWR International Eurolab. HPLC-grade methanol, dichloromethane, formic acid, and 
trifluoroacetic acid (TFA) were purchased from Merck (Darmstadt, Germany). Deionized water $\left(>18 \mathrm{M} \Omega \mathrm{cm}^{-1}\right.$ resistivity) was obtained from a Milli-Q water purification system (Millipore, Bedford, USA). BOND ELUT ${ }^{\circledR}$ Carbon cartridges (500 mg, $6 \mathrm{~mL}$ ) were supplied by Agilent Technologies (The Netherlands, Europe).

2.2. Collection of Aphanizomenon ovalisporum strain culture and determination of cyanobacterial toxins

Aphanizomenon ovalisporum (LEGE X-001) cyanobacterial CYN-producing strain (CYN+) was isolated from Lake Kinneret (Banker et al., 1997) and kindly supplied by Dr. Vitor Vasconcelos (Marine Research Centre, Porto, Portugal). A culture of this strain was maintained in $\mathrm{Z} 8$ medium at $25^{\circ} \mathrm{C}$ under continuous illumination with an intensity of $28 \mu \mathrm{mol}$ photons $\mathrm{m}^{-2} \mathrm{~s}^{-1}$ provided by cool white fluorescent tubes. After 33 days, cultures were harvested by decantation and filtration with plankton net $(20 \mu \mathrm{m}$ diameter). The biomass obtained was frozen at $-80^{\circ} \mathrm{C}$ until lyophilization (Telstar Cryodos, Madrid).

CYN extraction and purification with graphitized carbon cartridges from the lyophilized culture of A. ovalisporum ( $\mathrm{CYN}+$ ) was performed according to GuzmánGuillén et al. (2012), prior to its LC-MS/MS analysis. Chromatographic separation was performed using a Perkin Elmer Series 200 HPLC system (Wellesley, USA) coupled to an Applied Biosystems QTRAP LC/MS/MS system (Foster City, USA) consisting of an hybrid triple quadrupole linear ion trap $\left(\mathrm{QqQ}_{\text {lit }}\right)$ mass spectrometer equipped with an electrospray ion source. LC-MS/MS analyses were performed in the same conditions as in Guzmán-Guillén et al. (2013b), detecting CYN and deoxy-CYN in the sample culture.

\subsection{Experimental setup and acclimation of fish}

Seventy-two male $O$. niloticus (Nile tilapia, average weight: $50 \pm 8 \mathrm{~g}$, length: $12 \pm 2 \mathrm{~cm}$ ) were obtained from the fish hatchery "Aquaculture Valencia", maintained and acclimatized at the laboratory for 15 days in the same conditions as GuzmánGuillén et al. (2013b) before the beginning of the experiment.

\subsection{Experimental exposure}


After the acclimation period, 9 experimental groups ( 8 individuals per group) were established as shown in Table 1, according to Guzmán-Guillén et al. (2013b). Briefly, the groups considered were control group (aquarium 1), pure CYN control group (aquarium 2), lyophilized cells (containing CYN and deoxy-CYN) control group (aquarium 3), LC control groups (aquaria 4 and 7), and LC + CYN groups (aquaria 5, 6, 8 and 9) (Table 1). According to the treatment, each fish group was fed with a mixture of the corresponding components (fish food, pure CYN, toxic lyophilized cells, and different doses of LC), resulting in small sticky pellets. The amount of commercial fish food administered per fish was $0.5 \mathrm{~g} /$ day. Fish in aquarium 1 were daily fed with only commercial fish food. Fish in aquaria 2 and 3 were daily fed with commercial fish food for 21 days and, on day 21, together with the food they received a single oral dose of pure CYN or lyophilized cells containing CYN and deoxy-CYN (400 $\mu \mathrm{g} \mathrm{CYN/kg} \mathrm{bw}$ fish). Fish in aquaria 4 and 7 were daily fed with commercial fish food plus 400 or 880 $\mathrm{mg} \mathrm{LC} / \mathrm{kg}$ bw fish (equivalent to 20 or $44 \mathrm{mg}$ LC/fish), respectively, for 21 days. Fish in aquaria 5, 6, 8 and 9 were daily fed with commercial fish food plus 400 or $880 \mathrm{mg}$ $\mathrm{LC} / \mathrm{kg}$ bw fish for 21 days and, on day 21, they received a single oral dose of pure CYN or lyophilized cells containing CYN and deoxy-CYN (400 $\mu \mathrm{g} \mathrm{CYN/kg} \mathrm{bw} \mathrm{fish).} 24 \mathrm{~h}$ after exposure to the toxin, fish from all groups were anaesthetized in ice and euthanized by transection of the spinal cord. Organs (liver, kidney, heart, intestines and gills) were quickly removed, weighed, rinsed with ice-cold saline, frozen in liquid nitrogen, and kept at $-80^{\circ} \mathrm{C}$ until further use. Doses of CYN and LC were selected according to Guzmán-Guillén et al. (2013b), who reported the beneficial antioxidant effects of LC dietary supplementation from $400 \mathrm{mg} \mathrm{LC} / \mathrm{kg}$ bw fish/day, for 21 days, on the oxidative stress status of different organs in tilapia exposed to pure CYN or lyophilized A. ovalisporum cells (400 $\mu \mathrm{g} \mathrm{CYN/kg} \mathrm{bw} \mathrm{fish).}$

\subsection{Light microscopy and electron microscopy}

Tissue samples were taken from the liver, kidney, heart, intestines, and gills of control and exposed fish for histological examination. For light microscopy, samples were first fixed in $10 \%$ buffered formalin for $24 \mathrm{~h}$ at $4^{\circ} \mathrm{C}$, and then immediately dehydrated in a graded series of ethanol, immersed in xylol and embedded in paraffin wax by using an automatic processor. Sections were processed according to GuzmánGuillén et al. (2015b). 
In case of electron microscopy (EM), samples were prefixed in $2 \%$ glutaraldehyde fixative (in $\mathrm{pH} 7.4$ phosphate buffer for $10 \mathrm{~h}$ at $4^{\circ} \mathrm{C}$ ) and postfixed in $1 \%$ osmium tetroxide fixative (in $\mathrm{pH} 7.4$ phosphate buffer for $0.5 \mathrm{~h}$ at $4^{\circ} \mathrm{C}$ ). Subsequently, they were dehydrated in a graded ethanol series and embedded in epon. Ultra thin sections $(50-60 \mathrm{~nm})$ were cut with a LKB microtome and were further processed according to Guzmán-Guillén et al. (2015b).

\subsection{Morphometric study}

For the structural quantifications, the fixed liver, kidney and heart were cut into three sections and each portion was then histologically processed, dehydrated in a graded series of ethanol, immersed in xylol and embedded in paraffin wax. Later, the fixed liver, kidney and heart were processed according to Guzmán-Guillén et al. (2015b). To quantify any alterations on hepatocytes size, the average diameter of the nuclei was employed; the average cross sections of the proximal and distal convoluted tubules and of cardiac fibers and capillaries were estimated in the case of the kidney and the heart, respectively.

\subsection{Statistical Analysis}

Data were analyzed by applying bivariate comparisons considering nonparametric methods. Differences among groups, with respect to hepatocyte nuclear diameters, convoluted tubules cross-sections, cardiac fiber and capillaries diameters values were tested using the Kruskal-Wallis test, whereas pair-wise differences were compared by the Tukey-Kramer test. The analyses were conducted using the Statistical software Statistica, version 6. Statsoft Inc. All reported $p$ values were two-tailed, with $p<0.05$ considered as significant.

\section{Results}

No fish died and no behavioural alterations were observed in any of the fish during the experiment. Moreover, no remarkable histopathological changes were observed in any of the studied organs of control fish (Figs. 1-5A, B) and fish treated only with L-Carnitine (Figs. 1-5C, D). Hence, only images from fish pretreated with one dose of LC was shown. 
Regarding the liver of control fish, apparently normal hepatocytes with cytoplasmic organelles and mitochondria are observed (Figs. 1A, B), and this normal structure was also found in liver of fish pretreated with $400 \mathrm{mg} \mathrm{LC} / \mathrm{kg}$ bw fish/day (Figs. 1C, D). The microscopic examination of the HE-stained liver sections of fish exposed to pure CYN revealed hepatic disorganization with presence of lipids (arrow) and glycogen (circle) in the cytoplasm (Fig. 1E). Ultrastructurally, hepatocytes showed a cytoplasm with large lipid vesicles (circle) displacing the cytoplasmic organelles, and granular glycogen (arrow) (Fig. 1F), being these alterations more accentuated than in the case of lyophilized A. ovalisporum cells. Fish exposed to lyophilized A. ovalisporum cells showed a disorganized parenchyma with great glycogen content in the cytoplasm (circle) and lipid droplets (arrow) (Figs. 1G, H). In fish pretreated with 400 or $880 \mathrm{mg}$ LC/kg bw fish/day, and exposed to CYN, the parenchyma showed an apparently normal cord-like structure, with numerous cytoplasmic organelles, absence of lipids and glycogen and abundant mitochondria (circle) (Figs. 1I, J, K, L). Fish pretreated with $400 \mathrm{mg} \mathrm{LC} / \mathrm{kg}$ bw fish/day and exposed to pure CYN presented cytoplasms with scarce glycogen content, without being a pathological process (figure not shown).

The kidney of control fish showed apparently normal glomeruli and tubules (Figs. 2A, B), as well as the structure presented by fish pretreated with $400 \mathrm{mg} \mathrm{LC} / \mathrm{kg}$ bw fish/day (Figs. 2C, D). Fish exposed to pure CYN or to lyophilized A. ovalisporum cells showed glomerular atrophy (circle), dilatation of Bowman's capsule (arrow) and tubulonephrosis (star) under light microscopy (Figs. 2E, G). Electron microscopy revealed hyalinized cells (arrow) and swelling with loss of microvilli of the proximal convoluted tubules (PCT) (circle) (Figs. 2F, H). Fish pretreated with 400 or $880 \mathrm{mg}$ $\mathrm{LC} / \mathrm{kg}$ bw fish/day prior to CYN intoxication presented normal renal structure with normal podocytes, abundant microvilli and mitochondria (circle) (Figs. 2I, J, K, L).

Apparently normal muscle fibers were observed in heart of control fish and fish pretreated with $400 \mathrm{mg} \mathrm{LC} / \mathrm{kg}$ bw fish/day (Figs. 3A, B, C, D). Fish exposed to both pure CYN and lyophilized A. ovalisporum cells showed myofibrolysis, loss of myofibrils (circles), abundant edema (star) and some haemorrhage (arrow), without significant differences among both treatments (Figs. 3E, F). Fish pretreated with LC and exposed to CYN presented a cardiac parenchyma with an apparently normal structure, with some haemorrhage (circle) in case of pretreatment with $400 \mathrm{mg} \mathrm{LC} / \mathrm{kg}$ bw fish/day 
(Fig. 3G, H), whereas normal myofibrils and abundant mitochondria (circle) were observed with the highest dose assayed ( $880 \mathrm{mg} \mathrm{LC/kg} \mathrm{bw} \mathrm{fish/day)} \mathrm{(Figs.} \mathrm{3I,} \mathrm{J).}$

Intestine samples from control fish exhibited apparently normal villi and enterocytes with abundant microvilli (circle) (Figs. 4A, B), as well as fish pretreated only with LC, which presented abundant caliciform cells (arrows) (Figs. 4C, D). Fish exposed to CYN revealed enteritis processes with abundance of necrotic enterocytes (circle) by light microscopy (Fig. 4E) and partial loss of microvilli (circle) under electronic microscopy (Fig. 4F). These lesions are very similar in treatments with pure CYN and lyophilized A. ovalisporum cells. Light microscopy of samples from fish pretreated with both doses of LC and exposed to the toxin exhibited normal structure and enterocytes, with abundant caliciform cells (arrows) (Figs. 4G, I). Ultrastructurally, the tissue showed abundant microvilli (circles), as well as caliciform cells with mucous granules and very active mitochondria (arrow) (Figs. 4H, J).

Gills of control fish showed an apparently normal structure (Figs. 5A, B), and LC pretreatment at both doses assayed did not alter this status (Figs. 5C, D). Injuries observed by light microscopy in gills of fish intoxicated with pure CYN were characterized by hyperemia in the secondary lamellae (arrows) and haemorrhage (circles) (Figs. 5E, G). The ultrastructural study showed gill arches with loss of continuity and cell infiltrates (circle) in the case of pure CYN (Fig. 5F) and with tumefaction (circle) when fish were exposed to lyophilized A. ovalisporum cells (Fig. $5 \mathrm{H}$ ), inducing more accentuated effects than pure CYN. Fish pretreated with the antioxidant and later exposed to CYN showed an apparently normal structure (Figs. 5 I, J).

Regarding the results obtained in the morphometric study in the liver, average hepatocyte nuclear diameters were not significantly augmented in fish exposed to pure CYN or to lyophilized A. ovalisporum cells (Fig. 6). LC administration did not induce any significant changes in this parameter either. In the kidney, the data concerning the average cross sections of the proximal convoluted tubules showed a significant increase in fish exposed both to pure CYN and to lyophilized A. ovalisporum cells (1.5-fold in both cases), in comparison to control fish, with no differences regarding the type of CYN employed. Pretreatment with LC in fish intoxicated with the toxin reduced these diameters, showing a total recovery of this parameter at both doses of LC assayed (Fig. 
7a). The average cross-sections of distal convoluted tubules showed significant increases in fish exposed to pure CYN (1.3-fold), which were restored to basal levels from $400 \mathrm{mg} \mathrm{LC} / \mathrm{kg}$ bw fish/day (Fig. 7b), in comparison to their respective groups of fish not supplemented with LC. Results from the morphometric study in heart revealed that toxin administration, regardless of the type of toxin, did not induce any significant changes in the cardiac fibers or capillaries diameters compared to their respective control groups. Moreover, LC per se did not alter these parameters either (Figs. 8a, b).

\section{Discussion}

To date, two substances have proved to be useful chemoprotectants for prevention of histopathological alterations in CYN-exposed fish. First, Gutiérrez-Praena et al. (2014) demonstrated that dietary NAC supplementation was able to reduce (22 $\mathrm{mg}$ $\mathrm{NAC/fish/day)} \mathrm{or} \mathrm{totally} \mathrm{prevent} \mathrm{(45} \mathrm{mg} \mathrm{NAC/fish/day)} \mathrm{histopathological} \mathrm{alterations} \mathrm{in}$ tilapia exposed to CYN. Then, we showed the beneficial effects of vitamin E $(25 \mathrm{mg}$ vitamin E/fish/day) on preventing similar lesions in the same organs of tilapia exposed to CYN (Guzmán-Guillén et al., 2015b). The main histopathological alterations found in several organs of CYN-exposed tilapia in the present work are in accordance with previous studies carried out in our laboratory with fish intoxicated with CYN (Gutiérrez-Praena et al., 2012c, 2014; Puerto et al., 2014; Guzmán-Guillén et al., 2015a). The novelty of the present work lies in the fact that LC was able to prevent the pathological changes induced in fish by CYN. In this sense, the mechanism underlying the protective effect of LC against histopathological damages induced by CYN in fish still remains unexplored, although LC antioxidant activity seems to be involved, as the results of histopathological scoring were compatible with the improved results of different oxidative stress parameters obtained by administration of this substance (Guzmán-Guillén et al., 2013b).

In the present study, pretreatment with LC reduced the alterations induced in liver of CYN-exposed fish, although a non-pathological glycogen accumulation still remained only with the lowest dose of $20 \mathrm{mg}$ LC/fish/day in fish intoxicated with pure CYN. However, a total recovery was obtained in fish pretreated with the highest dose of LC (44 mg LC/fish/day), in a similar way as Gutiérrez-Praena et al. (2014) demonstrated in fish pretreated with NAC and intoxicated with CYN. L-carnitine has been associated with a protective effect in experimental IR injury models regarding the 
liver, kidney, heart, skeletal muscle, spinal cord, and skin flaps (Canbaz et al., 2007; Mister et al., 2002; Xie et al., 2006; Patel et al., 2012). Demirdag et al. (2004) demonstrated that $\mathrm{CCl}_{4}$-induced steatosis, inflammation and necrosis were significantly reduced in rats which received subcutaneous LC. Moreover, its administration significantly reduced the degree of pathologic alterations induced by acetaminophen in liver of mice (necrosis, hyperemia, sinusoidal congestion and haemorrhages) (Yapar et al., 2007). Li et al. (2012) demonstrated that human hepatocyte cells exposed to $\mathrm{H}_{2} \mathrm{O}_{2}$ showed decreased expressions of peroxisome proliferator-activated receptor alpha (PPAR- $\alpha$ ), carnitine palmitoyl transferase 1 (CPT1) and acyl-CoA oxidase (ACOX), leading to attenuated lipid metabolism which would be significantly improved by LC, due to its role in fatty acids $\beta$-oxidation.

Regarding the kidney, LC pretreatment managed to prevent completely the lesions induced in this organ by exposure to CYN, from the dose of $20 \mathrm{mg} \mathrm{LC/fish/day,}$ obtaining the same protection with the highest dose of $44 \mathrm{mg} \mathrm{LC/fish/day.} \mathrm{This} \mathrm{is} \mathrm{in}$ agreement with other studies that obtained similar protection against CYN toxicity conferred by NAC with 22 and $45 \mathrm{mg} /$ fish/day (Gutiérrez-Praena et al., 2014) and by vitamin E with $25 \mathrm{mg} /$ fish/day (Guzmán-Guillén et al., 2015b). However, in the present study LC was effective in preventing the adverse effects of twice the CYN dose assayed by Gutiérrez-Praena et al. (2014) (400 versus $200 \mu \mathrm{g}$ CYN/kg bw fish). Furthermore, in a previous study carried out with NAC and MCs, this antioxidant showed to have prooxidant properties at the highest dose assayed (96.8 $\mathrm{mg} \mathrm{NAC} /$ fish/day, for 7 days) (Puerto et al., 2010), whereas in the present work, $44 \mathrm{mg}$ LC/fish/day supplied for 21 days did not show any pro-oxidant effects per se, and prevented the adverse effects of the toxin. This comparison may lead to think of better protective properties of LC as antioxidant, compared to NAC. Previous works have described the antioxidant properties of L-carnitine and propionyl-L-carnitine (PLC) in preventing renal function deterioration due to IR (Mister et al., 2002; Gorur et al., 2005; Rabie et al., 2012). According to Rabie et al. (2012), the favourable effects of LC are probably mediated by virtue of its antioxidants and anti-inflammatory effects or its ability to increase the intracellular carnitine content, with a consequent improvement in mitochondrial oxidative phosphorylation and energy production. The antioxidant capacity of LC has been demonstrated by prevention of nephrotoxicity induced in rats by exposure to cisplatin (Sayed-Ahmed et al., 2004). Xiang et al. (2013) recently suggested that 
inhibition of tubulointerstitial inflammation by LC in cyclosporine-exposed rats occurred via the suppression of macrophage influx.

In the present study, the fact that morphometric alterations were only visible in the kidney could be reflecting the more susceptible nature of this organ by exposure to CYN. LC pretreatment, from the lowest dose assayed (20 mg LC/fish/day), was effective in preventing the increases induced by CYN in the cross sections of the proximal and distal tubules. This protection observed is in accordance with that obtained by Guzmán-Guillén et al. (2015b), where fish were supplemented with vitamin E for 7 days before $24 \mathrm{~h}$-exposure to pure CYN.

The heart was the only organ which needed the highest dose of LC (44 $\mathrm{mg} /$ fish/day) to totally prevent the histopathological lesions induced by CYN in it, obtaining a partial amelioration of the effects with the lowest LC dose ( $20 \mathrm{mg} / \mathrm{fish} /$ day $)$. The same pattern was observed in tilapia pretreated with NAC and vitamin E and intoxicated with pure CYN (Gutiérrez-Praena et al., 2014; Guzmán-Guillén et al., 2015b). Our results are in accordance with the protection shown by LC in cisplatinexposed rats which also had developed myofibrolysis, edema and haemorrhage, with a marked decrease in ATP levels in heart tissues that would render the cardiac cells vulnerable to damage by cisplatin (Al-Majed et al., 2006). This is explained because LC plays a protective role in metabolic disorders and a critical role in the energy metabolism of tissues that derive a considerable part of their metabolic energy from fatty acid oxidation, such as heart, skeletal muscle, liver and placenta (Shekhawat et al., 2007). Thus, in our study it seems that LC supplementation prevented CYN-induced decrease in ATP by replenishing the myocardium with adequate carnitine for its energy production. Moreover, LC could have ameliorated CYN effects in the heart due to its participation in fatty acid $\beta$-oxidation, as cardiac hypertrophy is associated with decreases in this process (Bernardo et al., 2010). LC and PLC possess an anti-ischemic action after IR injury and improve endothelial dysfunction in hypertensive rats, enhancing the recovery of myocardial function and various metabolic parameters. This is partly due to their antioxidant activity, prevention of energy loss and increased NO participation in endothelium-dependent relaxations in hypertensive rats (Packer et al., 1991; Paulson et al., 1995; Xie et al., 2006; Bueno et al., 2005). However, only LC was able to increase the release of the vasodilator PGI2 and even enhanced TXA2 production in normotensive rats (Bueno et al., 2005). LC ability to increase NO 
production (De Marchi et al., 2012) and to restore myocardial energy reserves (Dayanand et al., 2011) were also the interpretation of Strilakou et al. (2013) for the prevention of cardiac interstitial edema and dysfunction in choline-deficient rats by administration of $200 \mathrm{mg} \mathrm{LC} / \mathrm{kg}$ bw/day, for 4 weeks. Whereas these authors hypothesized about the possible carnitine-induced heart toxicity at higher doses than the assayed of $200 \mathrm{mg} \mathrm{LC} / \mathrm{kg}$ bw, in our study we did not find that 400 or $800 \mathrm{mg} \mathrm{LC} / \mathrm{kg}$ bw administered to fish produced any damage itself.

Supplementation with LC was able to decrease totally the enteritis and necrosis induced by CYN in the gastrointestinal (GI) tract in this work. This prevention was offered from the lowest dose of $20 \mathrm{mg}$ LC/fish/day, in agreement with the protection shown by NAC and vitamin E against CYN-intoxication (Gutiérrez-Praena et al., 2014; Guzmán-Guillén et al., 2015b). A similar protection by LC was observed in the gastric mucosa of rats exposed to ethanol (Dokmeci et al., 2005) or with small intestinal IR injury, by inhibition of proinflammatory cytokines secretion (Yuan et al., 2011), partly due to LC capacity to enhance mitochondrial energy metabolism, in agreement with the activation of mitochondria in fish pretreated with LC in our study. The role of carnitine in the GI tract became a topic of discussion, and some authors suggested that fatty acid oxidation facilitated by carnitine may be obligatory for the maintenance of normal gut morphology and function in mice (Shekhawat et al., 2007).

In this work, LC pretreatment prevented completely the lesions induced in gills by exposure to CYN, even the tumefaction induced by lyophilized cells, from $20 \mathrm{mg}$ $\mathrm{LC} /$ fish/day, in agreement with the protection offered by NAC and vitamin E against CYN toxicity (Gutiérrez-Praena et al., 2014) and by vitamin E with $25 \mathrm{mg} / \mathrm{fish} /$ day (Guzmán-Guillén et al., 2015b). Schreiber et al. (1997) showed that $1100 \mathrm{mg} \mathrm{LC} / \mathrm{kg}$ diet protected gills and skin of reproducing guppies (Poecilla reticulate) from anionic xenobiotics under heat stress, probably due to LC interaction with cardiolipin, resulting in protection of mitochondrial membranes and functions, with enhanced stability and impermeability of epithelial layers in the gills presumably by regeneration of damaged foci and stimulation of cellular energetic metabolism. A similar protection was provided by a lower level of carnitine supplementation (150 mg LC/kg diet) in gills of hybrid tilapia reared under intensive pond culture conditions (Schlechtriem et al., 2004). This mechanism could also explain the protective effects of LC against the injuries induced by CYN in gills in our work. 
Likewise in other organs and tissues, acetyl-L-carnitine resulted in improvement of mitochondrial function in rats after spinal cord injury, due perhaps to the membrane stabilization conferred by the synthesis of lipids/phospholipids (Patel et al., 2012). Mitochondrial alteration and damages as a consequence of CYN exposure were also observed in Caco-2 cells (Gutiérrez-Praena et al., 2012b). Furthermore, the mitochondrial membrane potential (MMP) was increased in CYN-treated HepG2 cells (Štraser et al., 2013), and it is known that a high MMP is positively correlated with the production of ROS (Suski et al., 2012). According to Sieroslawska and Rymuszka (2015), the relationship between ROS level and mitochondrial status in CYN-treated cells has not been studied yet. Thus, taking into account the previous works demonstrating the amelioration by LC of mitochondrial damage by different xenobiotics and/or injuries, we assume that LC was able to prevent the lesions in the mitochondrial proteins target of CYN in our study. This could be evidenced by the very active mitochondria observed in LC-pretreated fish before exposure to the toxin. This is important due to the implications that the possible injuries in mitochondrial proteins may have in production of structures and/or in metabolic processes. In general, the protection offered by LC in the present work against the lesions found seems to be a result of its role in $\beta$-oxidation, its superoxide scavenger and antioxidant capacity, antiischemic action, and stabilizing effect on mitochondrial function and cell membranes (Muthuswamy et al., 2006; Canbaz et al., 2007).

Our results present an advantage of LC application compared to the other antioxidants previously tested against cyanotoxins-intoxication. In general, NAC offered only a partial protection against histopathological changes induced by MCs or CYN with 20 or $22 \mathrm{mg} \mathrm{NAC/fish,} \mathrm{needing} \mathrm{normally} \mathrm{the} \mathrm{highest} \mathrm{dose} \mathrm{(44} \mathrm{or} 45 \mathrm{mg}$ NAC/fish) for a total prevention (Puerto et al., 2010; Gutiérrez-Praena et al., 2014). Moreover, NAC showed pro-oxidant properties at the highest dose assayed (Puerto et al., 2010). However, in the present work, the lowest dose tested (20 mg LC/fish) was generally sufficient for a complete prevention of CYN-induced histopathological lesions in all organs, except in the heart, where $44 \mathrm{mg} \mathrm{LC} /$ fish were needed to achieve it. Regarding vitamin E, its pro-oxidant activity at high doses in vivo has been demonstrated (Pearson et al., 2006), although supplementation of fish with $25 \mathrm{mg}$ vitamin E/fish did not show this activity per se (Guzmán-Guillén et al., 2015a,b). In the present work, LC high water-solubility leads to think that toxicity associated with its 
excessive administration would not be so plausible in fish and the excess carnitine would be degraded, so the negative impact would be mainly on the cost of the feed. According to Harpaz (2005), the need for high levels of LC may not be very effective because of its cost; thus, the fact that we have found protection at the lowest dose assayed is another advantage for its use.

\section{Conclusions}

This work demonstrates for the first time that LC pretreatment (400 or $880 \mathrm{mg}$ $\mathrm{LC} / \mathrm{kg}$ bw fish, equivalent to 20 or $44 \mathrm{mg} \mathrm{LC/fish/day),} \mathrm{is} \mathrm{able} \mathrm{to} \mathrm{prevent} \mathrm{or} \mathrm{ameliorate}$ the histopathological alterations induced in liver, kidney, heart, intestines and gills of tilapia (O. niloticus) acutely exposed to pure CYN or to A. ovalisporum cells containing CYN and deoxy-CYN (400 $\mu \mathrm{g}$ CYN/kg fish bw). Therefore, LC might be used in advance as a preventive measure to reduce histopathological and morphometric changes in fish resulting from the exposure to CYN.

\section{Acknowledgements}

This work was supported by the Ministerio de Ciencia e Innovación of Spain (AGL2009-10026) and the Junta de Andalucía (P09-AGR-4672). The authors would like to acknowledge the European Cooperation in Science and Technology, COST Action ES 1105 "CYANOCOST-Cyanobacterial blooms and toxins in water resources: Occurrence, impacts and management" for adding value to this study through networking and knowledge sharing with European experts and researchers in the field. Remedios Guzmán Guillén also gratefully acknowledges the Spanish Ministerio de Educación for her grant "Formación del Profesorado Universitario (FPU)". 


\section{References}

Al-Majed AA, Sayed-Ahmed MM, Al-Yahya AA, Mleisa AM, Al-Rejaie SS, AlShabanah OA. 2006. Propionyl-L-carnitine prevents the progression of cisplatininduced cardiomyopathy in a carnitine-depleted rat model. Pharmacol Res 53:278286.

Atencio L, Moreno IM, Jos A, Prieto AI, Moyano R, Blanco A, Cameán AM. 2009. Effects of dietary selenium on the oxidative stress and pathological changes in tilapia (Oreochromis niloticus) exposed to a microcystin-producing cyanobacterial water bloom. Toxicon 53:269-282.

Banker R, Carmeli S, Hadas O, Teltsch B, Porat R, Sukenik A, 1997. Identification of cylindrospermopsin in Aphanizomenon ovalisporum (cyanophyceae) isolated from lake Kinneret, Israel. J Phycology 33:613-616.

Bazin E, Mouro, A, Humpage AR, Fessard V. 2010. Genotoxicity of a freshwater cyanotoxin, cylindrospermopsin, in two human cell lines: Caco-2 and HepaRG. Environ Mol Mutagen 51:251-259.

Becker K, Focken U. 1995. Effects of feed supplementation with 1-carnitine on growth, metabolism and body composition of carp (Cyprinus carpio L.). Aquaculture 129:341-341. DOI: 10.1016/0044-8486(95)91980-A.

Bernardo BC, Weeks KL, Pretorius L, McMullen JR., 2010. Molecular distinction between physiological and pathological cardiac hypertrophy: experimental findings and therapeutic strategies. Pharmacol Ther 128:191-227.

Bueno R, Alvarez M, Perez-Guerrero C, Gomez-Amores L, Vazquez CM, Herrera MD. 2005. L-carnitine and propionyl-L-carnitine improve endothelial dysfunction in spontaneously hypertensive rats: different participation of NO and COX-products. Life Sci 77:2082-2097. 
Canbaz H, Akca T, Tataroglu C, Caglikulekci M, Dirlik M, Ayaz L, Ustunsoy AB, Tasdelen B, Aydin S. 2007. The Effects of Exogenous L-Carnitine on Lipid Peroxidation and Tissue Damage in an Experimental Warm Hepatic IschemiaReperfusion Injury Model. Curr Ther Res Clin Exp 68:32-46.

Chatzifotis S, Takeuchi T, Seikai T. 1995. The effect of dietary L-carnitine on growth performance and lipid composition in red sea bream fingerlings. Fish Sci 61:10041008.

Dayanand A, Kumar P, Panneerselvam C. 2001. Protective role of L-carnitine on liver and heart lipid peroxidation in atherosclerotic rats. J Nutr Biochem 12:254-257.

De Marchi S, Zecchetto S, Rigoni A, Prior M, Fondrieschi L, Scuro A, Rulfo F, Arosio E. 2012. Propionyl-L-carnitine improves endothelial function, micro- circulation and pain management in critical limb ischemia. Cardiovasc Drugs Ther 26:401408 .

Derin N, Izgut-Uysal VN, Agac A, Aliciguzel Y, Demir N. 2004. L-carnitine protects gastric mucosa by decreasing ischemiae reperfusion induced lipid peroxidation. $\mathrm{J}$ Physiol Pharmacol 55:595-606.

Demirdag K, Bahcecioglu IH, Ozercan IH, Ozden M, Yilmaz S, Kalkan A. 2004. Role of L-carnitine in the prevention of acute liver damage induced by carbon tetrachloride in rats. J Gastroenterol Hepatol 19:333-338.

Dokmeci D, Akpolat M, Aydogdu N, Doganay L, Turan FN. 2005. L-carnitine inhibits ethanol-induced gastric mucosal injury in rats. Pharmacol Rep 57:481-488.

Falconer IR, Hardy SJ, Humpage AR, Froscio SM, Tozer GJ. Hawkins PR. 1999. Hepatic and renal toxicity of the blue-green alga (cyanobacterium) Cylindrospermopsis raciborskii in male Swiss albino mice. Environ Toxicol $14: 143-150$. 
Folts JD, Shug AL, Koke JR, Bittar N. 1978. Protection of the ischemic dog myocardium with carnitine. Am J Cardiol 41:1209-1214.

Gómez-Amores L, Mate A, Miguel-Carrasco JL, Jiménez L, Jos A, Cameán AM, Revilla E, Santa-María C, Vázquez CM. 2007. L-Carnitine attenuates oxidative stress in hypertensive rats. J Nutr Biochem 18:553-540.

Gorur S, Bagdatoglu OT, Polat G. 2005. Protective effect of L-carnitine on renal ischaemia-reperfusion injury in the rat. Cell Biochem Funct 23:151-155.

Gutiérrez-Praena D, Jos MA, Pichardo S, Cameán AM. 2011a. Oxidative stress responses in tilapia (Oreochromis niloticus) exposed to a single dose of pure cylindrospermopsin under laboratory condition: Influence of exposure route and time of sacrifice. Aquat Toxicol 105:100-106.

Gutiérrez-Praena D, Pichardo S, Jos A, Cameán AM. 2011b. Toxicity and glutathione implication in the effects observed by exposure of the liver fish cell line PLHC-1 to pure Cylindrospermopsin. Ecotox Environ Saf 74:1567-1572.

Gutiérrez-Praena D, Pichardo S, Jos A, Moreno FJ, Cameán AM. 2012a. Alterations observed in the endothelial HUVEC cell line exposed to pure Cylindrospermopsin. Chemosphere 89:1151-1160.

Gutiérrez-Praena D, Pichardo S, Jos A, Moreno FJ, Cameán AM. 2012b. Biochemical and pathological toxic effects induced by the cyanotoxin Cylindrospermopsin on the human cell line Caco-2. Water Res 46:1566-1575.

Gutiérrez-Praena D, Jos MA, Pichardo S, Moyano R, Blanco A, Monterde JG, Cameán AM. 2012c. Time-dependent histopathological changes induced in tilapia (Oreochromis niloticus) after acute exposure to pure Cylindrospermopsin by oral and intraperitoneal route. Ecotox Environ Saf 76:102-113. 
Gutiérrez-Praena D, Puerto M, Prieto AI, Jos Á, Pichardo S, Vasconcelos VM, Cameán AM. 2012d. Protective role of dietary N-acetylcysteine on the oxidative stress induced by cylindrospermopsin in tilapia (Oreochromis niloticus). Environ Toxicol Chem 31:1548-1555.

Gutiérrez-Praena D, Risalde MA, Pichardo S, Jos Á, Moyano R, Blanco A, Vasconcelos V, Cameán AM. 2014. Histopathological and immunohistochemical analysis of Tilapia (Oreochromis niloticus) exposed to cylindrospermopsin and the effectiveness of N-Acetylcysteine to prevent its toxic effects. Toxicon 78:18-34.

Guzmán-Guillén R, Prieto AI, Moreno IM, González G, Soria-Díaz ME, Vasconcelos V, Cameán AM. 2012. Development and optimization of a method for the determination of Cylindrospermopsin from strains of Aphanizomenon cultures: Intra-laboratory assessment of its accuracy by using validation standards. Talanta 100:356-363.

Guzmán-Guillén R, Prieto AI, Vasconcelos VM, Cameán AM. 2013a. Cyanobacterium producing Cylindrospermopsin cause oxidative stress at environmentally relevant concentrations in sub-chronically exposed Tilapia (Oreochromis niloticus). Chemosphere 90:1184-1194.

Guzmán-Guillén R, Prieto AI, Vázquez CM, Vasconcelos V, Cameán AM. 2013b. The protective role of 1-carnitine against cylindrospermopsin-induced oxidative stress in tilapia (Oreochromis niloticus). Aquat Toxicol 132-133:141-150.

Guzmán-Guillén R, Prieto AI, Moreno I, Vasconcelos VM, Moyano R, Blanco A, Cameán AM. 2015a. Cyanobacterium producing cylindrospermopsin cause histopathological changes at environmentally relevant concentrations in subchronically exposed tilapia (Oreochromis niloticus). Environ Toxicol 30: 261277. 
Guzmán-Guillén R, Prieto Ortega AI, Gutiérrez-Praena D, Moreno IM, Moyano R, Blanco A, Cameán AM. 2015b. Vitamin E pretreatment prevents histopathological effects in tilapia (Oreochromis niloticus) acutely exposed to Cylindrospermopsin. Environ Toxicol (in press). DOI: 10.1002/tox.22152.

Guzmán-Guillén R, Prieto Ortega AI, Martín-Cameán A, Cameán AM. 2015c. Beneficial effects of vitamin $\mathrm{E}$ supplementation against the oxidative stress on Cylindrospermopsin-exposed tilapia (Oreochromis niloticus). Toxicon 104:24-42.

Harpaz S, Becker K, Blum R. 1999. The effect of dietary L-carnitine supplementation on cold tolerance and growth of ornamental cichlid fish (Pelvicachromis pulcher) - preliminary results. J Therm Biol 24:57-62.

Harpaz S. 2005. L-Carnitine and its attributed functions in fish culture and nutrition - a review. Aquaculture 249:3-21.

Hawkins PR, Runnegar MT, Jackson AR, Falconer IR. 1985. Severe hepatotoxicity caused by the tropical cyanobacterium (blue-green alga) Cylindrospermopsis raciborskii (Woloszynska) Seenaya and Subba Raju isolated from a domestic water supply reservoir. Appl Environ Microb 50:1292-1295.

Hawkins PR, Chandrasena NR, Jones GJ, Humpage AR, Falconer IR. 1997. Isolation and toxicity of Cylindrospermopsis raciborskii from an ornamental lake. Toxicon $35: 341-346$.

Humpage AR, Fenech M, Thomas P, Falconer IR. 2000. Micronucleus induction and chromosome loss in transformed human white cells indicate clastogenic and aneugenic action of the cyanobacterial toxin, Cylindrospermopsin. Mutat Res 472:155-161. 
Humpage A. 2008. Toxin types, toxicokinetics and toxicodynamics. In: Hudnel HK, editor. Cyanobacterial Harmful Algal Blooms. State of the Science and Research Needs. New York: Springer Press, volume 619, p 383-415.

Ibelings BW, Chorus I. 2007. Accumulation of cyanobacterial toxins in freshwater "seafood" and its consequences for public health: A review. Environ Pollut 150:177-192.

Jayaprakas V, Sambhu C, Sunil Kumar S. 1996. Effect of dietary L-carnitine on growth and reproductive performance of male Oreochromis mossambicus (Peters). Fish Technol 33:84-90.

Keene BW, Panciera DP, Atkins CE, Regitz V, Schmidt MJ, Shug AL. 1991. Myocardial L-carnitine deficiency in a family of dogs with dilated cardiomyopathy. J Am Vet Assoc 198:647-650.

Kinnear S. 2010. Cylindrospermopsin: A decade of progress on bioaccumulation research. Mar Drugs 8:542-564.

Li JL, Wang QY, Luan HY, Kang ZC, Wang CB. 2012. Effects of L-carnitine against oxidative stress in human hepatocytes: involvement of peroxisome proliferatoractivated receptor alpha. J Biomed Sci 19:32.

Mister M, Noris M, Szymczuk J, Azzollini N, Aiello S, Abbate M, Trochimowicz L, Gagliardini E, Arduini A, Perico N, Remuzzi G. 2002. Propionyl-l-carnitine prevents renal function deterioration due to ischemia/reperfusion. Kidney Int 61:1064-1078.

Moreira C, Azevedo J, Antunes A, Vasconcelos V. 2012. Cylindrospermopsin: occurrence, methods of detection and toxicology. J Appl Microbiol 114:605-620.

Muthuswamy AD, Vedagiri K, Ganesan M, Chinnakannu P. 2006. Oxidative stressmediated macromolecular damage and dwindle in antioxidant status in aged rat 
brain regions: role of L-carnitine and DL-alpha-lipoic-acid. Clin Chim Acta 368:84-92.

Norris RL, Eaglesham G, Pierens G, Shaw G, Smith MJ, Chiswell RK, Seawright AA, Moore MR. 1999. Deoxycylindrospermopsin, an analog of cylindrospermopsin from Cylindrospermopsis raciborskii. Environ Toxicol 14:163-165.

Ohtani I, Moore RE, Runnegar M. 1992. Cylindrospermopsin: a potent hepatotoxin from the blue-green alga Cylindrospermopsis raciborskii. Am Chem Soc 114:7941-7942.

Packer L, Valenza M, Serbinosa E, Starke-Reed P, Frost K, Kagan V. 1991. Free radical scavenging is involved in the protective effects of L-propionyl-carnitine against ischemia reperfusion injury of the heart. Arch Biochem Biophys 288:533-537.

Patel SP, Sullivan PG, Lyttle TS, Magnuson DS, Rabchevsky AG. 2012. Acetyl-Lcarnitine treatment following spinal cord injury improves mitochondrial function correlated with remarkable tissue sparing and functional recovery. Neuroscience 210:296-307.

Paulson DJ, Shug AL. 1995. Experimental evidence of the anti-ischemic effect of Lcarnitine. In: de Jong JW, Ferrari R, editors. The Carnitine System: A New Therapeutical Approach to Cardiovascular Diseases. 1st ed. Dordrecht, The Netherlands: Kluwer Academic Publishers. p 183-197.

Pearson P, Lewis SA, Britton J, Young IS, Fogarty A. 2006. The pro-oxidant activity of high-dose vitamin E supplements in vivo. Bio Drugs 20:271-273.

Prieto AI, Pichardo S, Jos A, Moreno I, Cameán AM. 2008. Protective role of vitamin E on the Microcystin-induced oxidative stress in tilapia fish (Oreochromis niloticus). Environ Toxicol Chem 27:1152-1159. 
Prieto AI, Jos A, Pichardo S, Moreno IM, Alvarez De Sotomayor M, Cameán AM. 2009. Time-dependent protective efficacy of trolox (vitamin E analog) against microcystin induced toxicity in tilapia (Oreochromis niloticus). Environ Toxicol 54:563-579.

Puerto M, Prieto AI, Pichardo S, Moreno I, Jos A, Moyano R, Cameán AM. 2009. Effects of dietary $\mathrm{N}$-acetylcysteine (NAC) on the oxidative stress induced in tilapia (Oreochromis niloticus) exposed to a microcystin-producing cyanobacterial water bloom. Environ Toxicol Chem 28:1679-1686.

Puerto M, Prieto AI, Jos A, Moreno IM, Moyano R, Blanco A, Cameán AM. 2010. Dietary N-Acetylcysteine (NAC) prevents histopathological changes in tilapias (Oreochromis niloticus) exposed to a microcystins-producing cyanobacterial water bloom. Aquaculture 306:35-48.

Puerto M, Jos MA, Pichardo S, Gutiérrez-Praena D, Cameán AM. 2011. Acute effects of pure Cylindrospermopsin on the activity and transcription of antioxidant enzymes in Tilapia (Oreochromis niloticus) exposed by gavage. Ecotoxicology 20:1852-1860.

Puerto M, Jos A, Pichardo S, Moyano R, Blanco A, Cameán AM. 2014. Acute exposure to pure Cylindrospermopsin results in oxidative stress and pathological alterations in tilapia (Oreochromis niloticus). Environ Toxicol 29:371-385.

Rabie MA, Zaki HF, Bahgat AK, Abd El-Latif HA. 2012. Angiotensin antagonists and renal ischemia/reperfusion: Possible modulation by L-carnitine. Bull Fac Pharm Cairo Univ 50:7-16.

Rebouche CJ. 1991. Ascorbic acid and carnitine biosynthesis. Am J Clin Nutr $54: 1147 \mathrm{~S}-1152 \mathrm{~S}$. 
Rodehutscord M. 1995. Effects of supplemental dietary L-carnitine on the growth and body composition of rainbow trout (Oncorhynchus mykiss) fed high-fat diets. J Anim Physiol Anim Nutr 73:276-279.

Runnegar MT, Kong SM, Zhong YZ, Ge JL, Lu SC. 1994. The role of glutathione in the toxicity of a novel cyanobacterial alkaloid cylindrospermopsin in cultured rat hepatocytes. Biochem Biophys Res Commun 201:235-241.

Santulli A, D'Amelio V. 1986. Effects of supplemental dietary carnitine on the growth and lipid metabolism of hatcheryreared sea bass (Dicentrarchus labrax L.). Aquaculture 59:177-186.

Sayed-Ahmed MM, Eissa MA, Kenawy SA, Mostafa N, Calvani M, Osman AM. 2004. Progression of cisplatin-induced nephrotoxicity in a carnitine-depleted rat model. Chemotherapy 50:162-170.

Schlechtriem C, Bresler V, Fishelson L, Rosenfeld M, Becker K. 2004. Protective effects of dietary 1-carnitine on tilapia hybrids (Oreochromis niloticus $\mathrm{x}$ Oreochromis aureus) reared under intensive pond-culture conditions. Aquac Nutr 10:55-63.

Schreiber S, Becker K, Bresler V, Fishelson L. 1997. Dietary 1-carnitine protects the gills and skin of guppies (Poecilia reticulata) against anionic xenobiotics. Comp Biochem Physiol 117:99-102.

Seifert M, McGregor G, Eaglesham G, Wickramasinghe W, Shaw G. 2007. First evidence for the production of cylindrospermopsin and deoxy-cylindrospermopsin by the freshwater benthic cyanobacterium, Lyngbya wollei (Farlow ex Gomont) Speziale and Dyck. Harmful Algae 6:73-80.

Shaw GR, Sukenik A, Livne A, Chiswell RK, Smith MJ, Seawright AA, Norris RL, Eaglesham GK, Moore MR. 1999. Blooms of the cylindrospermopsin containing 
cyanobacterium, Aphanizomenon ovalisporum (Forti) in newly constructed lakes, Queensland, Australia. Environ Toxicol 14:167-177.

Shekhawat PS, Srinivas SR, Matern D, Bennett MJ, Boriack R, George V, Xu H, Prasad PD, Roon P, Ganapathy V. 2007. Spontaneous development of intestinal and colonic atrophy and inflammation in the carnitine-deficient $j v s\left(\mathrm{OCTN} 2^{-/-}\right)$mice. Mol Genet Metab 92:315-324.

Sieroslawska A and Rymuszka A. 2015. Cylindrospermopsin induces oxidative stress and genotoxic effects in the fish CLC cell line. J Appl Toxicol 35:426-433.

Sivonen K and Jones G. 1999. Cyanobacterial Toxins. In: Chorus I and Bartram MJ, editors. Toxic Cyanobacteria in Water: A guide to Their Public Health Consequences, Monitoring and Management. London: E \& FN Spon. p 41-111.

Štraser A, Filipič M, Gorenc I, Žegura B. 2013. The influence of cylindrospermopsin on oxidative DNA damage and apoptosis induction in HepG2 cells. Chemosphere 92:24-30.

Strilakou AA, Lazaris AC, Perelas AI, Mourouzis IS, Douzis I, Karkalousos PL, Stylianaki AT, Pantos CI, Liapi CA. 2013. Heart dysfunction induced by cholinedeficiency in adult rats: the protective role of L-carnitine. Eur $\mathrm{J}$ Pharmacol 709:20-27.

Suski JM, Lebiedzinska M, Bonora M, Pinton P, Duszynski J, Wieckowski MR. 2012. Relation between mitochondrial membrane potential and ROS formation. Methods Mol Biol 810:183-205.

Terao K, Ohmori S, Igarashi K, Ohtani I, Watanabe MF, Harada KI, Ito E, Watanabe M. 1994. Electron microscopic studies on experimental poisoning in mice induced by cylindrospermopsin isolated from blue-green alga Umezakia natans. Toxicon 32:833-843. 
Torreele E, Van der Sluizen A, Verreth J. 1993. The effect of dietary L-carnitine on the growth performance in fingerlings of the African catfish Clarias gariepinus.in relation to dietary lipid. Br. J Nutr 69:289-299.

Tremblay GC and Bradley TM. 1992. L-Carnitine protects fish against acute ammonia toxicity. Comp Biochem Physiol 101:349-351.

Wimmer KM, Strangman WK, Wright JLC. 2014. 7-Deoxy-desulfocylindrospermopsin and 7-deoxy-desulfo-12-acetylcylindrospermopsin: Two new cylindrospermopsin analogs isolated from a Thai strain of Cylindrospermopsis raciborskii. Harmful Algae 37:203-206.

Xiang Y, Piao SG, Zou HB, Jin J, Fang MR, Lei DM, Gao BH, Yang CW, Li C. 2013. L-carnitine protects against cyclosporine-induced pancreatic and renal injury in rats. Transplant Proc 45:3127-3134.

Xie J, Zeng Q, Wang L. 2006. The protective effect of L-carnitine on ischemiareperfusion heart. J Huazhong Univ Sci Technolog Med Sci 26:188-191.

Yang D-S, Liu F-G, Liou C-H. 2012. Effects of dietary L-carnitine, plant proteins and lipid levels on growth performance, body composition, blood traits and muscular carnitine status in juvenile silver perch (Bidyanus bidyanus). Aquaculture 342:4855.

Yapar K, Kart A, Karapehlivan M, Atakisi O, Tunca R, Erginsoy S, Citil M. 2007. Hepatoprotective effect of L-carnitine against acute acetaminophen toxicity in mice. Exp Toxicol Pathol 59:121-128.

Yuan Y, Guo H, Zhang Y, Zhou D, Gan P, Liang DM, Chen JY. 2011. Protective effects of L-carnitine on intestinal ischemia/reperfusion injury in a rat model. $\mathbf{J}$ Clin Med Res 3:78-84. 


\section{Figure legends}

Fig. 1. Histopathological changes in liver of Tilapia (Oreochromis niloticus) exposed to a single dose of $400 \mu \mathrm{g}$ pure CYN/kg fish bw, and pretreated with 400 or $880 \mathrm{mg} \mathrm{LC} / \mathrm{kg}$ fish/day for 21 d. (A, C, E, G, I, K): HE-stained liver sections. Bars: $10 \mu \mathrm{m}$. (B, D, F, H, J, L): Ultrastructural observations. Bars: $10 \mu \mathrm{m}$. (A, B) Control fish: (A) Normal hepatic cords, hepatocyte with an apparently normal morphology; (B) Detail of apparently normal hepatocytes with cytoplasmic organelles and mitochondria. (C, D) Tilapia pretreated with $400 \mathrm{mg}$ LC/kg fish/day, for 21 days: (C) Parenchyma with an apparently normal morphology, with hepatocytes arranged in cords and normal pancreatic area; (D) Detail of apparently normal hepatocytes with cytoplasmic organelles and absence of lipids and granular glycogen. (E, F) Tilapia exposed to a single dose of $400 \mu \mathrm{g}$ pure CYN/kg fish bw: (E) Disorganized hepatic parenchyma, hepatocytes with presence of glycogen (circle) and lipid vesicles (arrow); (F) The hepatocyte cytoplasm appears with a few organelles but full of lipids (circle) and slight presence of granular glycogen (arrow). (G, H) Tilapia exposed to lyophilized $A$. ovalisporum cells containing CYN (400 $\mu \mathrm{g}$ CYN/kg fish): (G) Disorganized hepatic parenchyma, hepatocytes with presence of glycogen (circles); (H) Disorganized parenchyma with great glycogen content in the cytoplasm (circle) and lipid droplets (arrow) (I, J) Tilapia pretreated with $400 \mathrm{mg} \mathrm{LC} / \mathrm{kg}$ fish/day for 21 days and exposed to lyophilized A. ovalisporum cells containing CYN (400 $\mu \mathrm{g}$ CYN/kg fish): (I) Apparently normal parenchyma showing the normal cord-like structure of hepatocytes; (J) Detail of apparently normal hepatocytes with cytoplasmic organelles and no lipids and granular glycogen. (K, L) fish pretreated with $880 \mathrm{mg} \mathrm{LC} / \mathrm{kg}$ fish/day for 21 days and exposed to lyophilized A. ovalisporum cells containing CYN (400 $\mu \mathrm{g}$ CYN/kg fish): (K) Apparently normal hepatic parenchyma; (L) Detail of apparently normal hepatocytes, with abundant mitochondria (circle).

Fig. 2. Histopathological changes in kidney of Tilapia (Oreochromis niloticus) exposed to a single dose of $400 \mu \mathrm{g}$ pure CYN/kg fish bw, and pretreated with 400 or $880 \mathrm{mg}$ LC/kg fish/day for $21 \mathrm{~d}$. (A, C, E, G, I, K): HE-stained liver sections. Bars: $10 \mu \mathrm{m}$. (B, D, F, H, J, L): Ultrastructural observations. Bars: $10 \mu \mathrm{m}$. (A, B) Apparently normal 
glomeruli and tubules. (C, D) Tilapia pretreated with $400 \mathrm{mg} \mathrm{LC} / \mathrm{kg}$ fish/day, for 21 days: (C) Apparently normal glomeruli and tubules; (D) Apparently normal proximal convoluted tubule (PCT). (E, F) Tilapia exposed to a single dose of $400 \mu \mathrm{g}$ pure CYN/kg fish bw: (E) Glomerulonephritis, glomerular atrophy (circle), dilation of Bowman's capsule (arrow) and tubulonefrosis (star); (F) Tubulonefrosis of proximal convoluted tubules (PCT) with thickened and hyalinized cells (arrow). (G, H) Tilapia exposed to lyophilized A. ovalisporum cells containing CYN (400 $\mu \mathrm{g} \mathrm{CYN/kg} \mathrm{fish):} \mathrm{(G)}$ Glomerulopathy and glomerular atrophy (circle), dilation of Bowman's capsule (arrow) and slight tubulonefrosis (star); (H) Tumefaction and loss of microvilli from the proximal convoluted tubules (PCT) (circle). (I, J) Tilapia pretreated with $400 \mathrm{mg} \mathrm{LC} / \mathrm{kg}$ fish/day for 21 days and exposed to $400 \mu \mathrm{g}$ pure CYN/kg fish bw: (I) Apparently normal glomeruli and tubules; (J) Proximal convoluted tubule (PCT) apparently normal, with abundant microvilli. (K, L) Tilapia pretreated with $880 \mathrm{mg} \mathrm{LC} / \mathrm{kg}$ fish/day for 21 days and exposed to $400 \mu \mathrm{g}$ pure CYN/kg fish bw: (K) Apparently normal hepatic parenchyma; (L) Detail of apparently normal distal convoluted tubule (DCT) with abundant mitochondria (circle).

Fig. 3. Histopathological changes in heart of Tilapia (Oreochromis niloticus) exposed to a single dose of $400 \mu \mathrm{g}$ pure CYN/kg fish bw, and pretreated with 400 or $880 \mathrm{mg} \mathrm{LC} / \mathrm{kg}$ fish/day for 21 d. (A, C, E, G, I): HE-stained liver sections. Bars: $10 \mu \mathrm{m}$. (B, D, F, H, J): Ultrastructural observations. Bars: $10 \mu \mathrm{m}$. (A, B) Apparently normal muscle fibers. (C, D) Tilapia pretreated with $400 \mathrm{mg} \mathrm{LC} / \mathrm{kg}$ fish/day, for 21 days: (C) Apparently normal muscle fibers; (D) Detail of apparently normal myofibrils with perfectly arranged and normal bands. (E, F) Tilapia exposed to a single dose of $400 \mu \mathrm{g}$ pure CYN/kg fish bw or to lyophilized A. ovalisporum cells containing CYN (400 $\mu \mathrm{g}$ CYN/kg fish): (E) Myofibrolysis, loss of myofibrils (circles), abundant edema (star) and certain haemorrhage (arrow); (F) Loss and disintegration of myofibrils (circle). (G, H) Tilapia pretreated with $400 \mathrm{mg} \mathrm{LC} / \mathrm{kg}$ fish/day for 21 days and exposed to lyophilized A. ovalisporum cells containing CYN (400 $\mu \mathrm{g}$ CYN/kg fish): (G) Apparently normal muscle fibers but some haemorrhage (circle); (H) Detail of normal myofibrils without loss of contractile material. (I, J) Tilapia pretreated with $880 \mathrm{mg} \mathrm{LC} / \mathrm{kg}$ fish/day for 21 
days and exposed to lyophilized A. ovalisporum cells containing CYN (400 $\mu \mathrm{g} \mathrm{CYN/kg}$ fish): (I) Apparently normal muscle fibers; (J) Normal myofibrils and abundant mitochondria (circle).

Fig. 4. Histopathological changes in gastrointestinal tract of Tilapia (Oreochromis niloticus) exposed to a single dose of $400 \mu \mathrm{g}$ pure CYN/kg fish bw, and pretreated with 400 or $880 \mathrm{mg} \mathrm{LC} / \mathrm{kg}$ fish/day for $21 \mathrm{~d}$. (A, C, E, G, I): HE-stained liver sections. Bars: $100 \mu \mathrm{m}$. (B, D, F, H, J): Ultrastructural observations. Bars: $10 \mu \mathrm{m}$. (A, B) Control fish: (A) Apparently normal intestinal villi and enterocytes; (B) Enterocytes with abundant microvilli apparently normal and caliciform cells (circle). (C, D) Tilapia pretreated with $400 \mathrm{mg} \mathrm{LC} / \mathrm{kg}$ fish/day, for 21 days: (C) Apparently normal villi and enterocytes with abundant caliciform cells (arrow); (D) Enterocytes with apparently normal and abundant caliciform cells (arrows). (E, F) Tilapia exposed to a single dose of $400 \mu \mathrm{g}$ pure CYN/kg fish bw or to lyophilized A. ovalisporum cells containing CYN (400 $\mu \mathrm{g}$ CYN/kg fish): (E) Detail of intestinal villi with necrotic enterocytes (circle); (F) Detail of enterocytes with partial loss of microvilli (circle). (G, H) Tilapia pretreated with 400 $\mathrm{mg} \mathrm{LC} / \mathrm{kg}$ fish/day for 21 days and exposed to $400 \mu \mathrm{g}$ pure CYN/kg fish bw or to lyophilized A. ovalisporum cells containing CYN (400 $\mu \mathrm{g}$ CYN/kg fish): (G) Apparently normal villi with normal enterocytes and abundant caliciform cells (arrow); (H) Apparently normal enterocytes with abundant microvilli (circle). (I, J) Tilapia pretreated with $880 \mathrm{mg} \mathrm{LC} / \mathrm{kg}$ fish/day for 21 days and exposed to $400 \mu \mathrm{g}$ pure CYN/kg fish bw or to lyophilized A. ovalisporum cells containing CYN (400 $\mu \mathrm{g} \mathrm{CYN/kg} \mathrm{fish):}$ (I) Apparently normal villi with apparently normal enterocytes and abundant caliciform cells (arrow); (J) Enterocytes with abundant microvilli (circle) and abundant very active mitochondria (arrow).

Fig. 5. Histopathological changes in gills of Tilapia (Oreochromis niloticus) exposed to a single dose of $400 \mu \mathrm{g}$ pure CYN/kg fish bw, and pretreated with 400 or $880 \mathrm{mg} \mathrm{LC} / \mathrm{kg}$ 
fish/day for 21 d. (A, C, E, G, I): HE-stained liver sections. Bars: $10 \mu \mathrm{m}$. (B, D, F, H, J): Ultrastructural observations (SEM). Bars: $10 \mu \mathrm{m}$. (A, B) Control fish. (C, D) Tilapia pretreated with $400 \mathrm{mg} \mathrm{LC} / \mathrm{kg}$ fish/day, for 21 days: (C) Detail of gills with a normal structure; (D) Apparently normal structure of lamellae. (E, F) Tilapia exposed to a single dose of $400 \mu \mathrm{g}$ pure CYN/kg fish bw: (E) Detail of gill filament with hyperemia in secondary lamellae (arrow) and haemorrhage (circle); (F) Gill arch with loss of continuity, erosion and cell infiltrate (circle). (G, H) Tilapia exposed to lyophilized $A$. ovalisporum cells containing CYN (400 $\mu \mathrm{g}$ CYN/kg fish): (G) Detail of gill filament with presence of hyperemia (arrow) and haemorrhage (circle) in secondary lamellae; (H) Gill arch surface with erosion and tumefaction (circle). (I, J) Tilapia pretreated with $400 \mathrm{mg} \mathrm{LC} / \mathrm{kg}$ fish/day for 21 days and exposed to a single dose of $400 \mu \mathrm{g}$ pure CYN/kg fish bw or to lyophilized A. ovalisporum cells containing CYN (400 $\mu \mathrm{g}$ CYN/kg fish): (I) Apparently normal gill filament; (J) Gill arch apparently normal.

Fig. 6. Hepatocyte nuclear diameters values $(\mu \mathrm{m})$ of Tilapia (Oreochromis niloticus) exposed to a single dose of $400 \mu \mathrm{g}$ pure CYN/kg fish bw or to lyophilized $A$. ovalisporum cells containing CYN ( $400 \mu \mathrm{g}$ CYN/kg fish), and pretreated with 400 or $880 \mathrm{mg} \mathrm{LC} / \mathrm{kg}$ fish/day for $21 \mathrm{~d}$. The values are expressed as mean $\pm \mathrm{sd}(n=5)$.

Fig. 7. Proximal (a) and Distal (b) convoluted tubules cross sections $(\mu \mathrm{m})$ of Tilapia (Oreochromis niloticus) exposed to a single dose of $400 \mu \mathrm{g}$ pure CYN/kg fish bw or to lyophilized A. ovalisporum cells containing CYN (400 $\mu \mathrm{g} \mathrm{CYN/kg} \mathrm{fish),} \mathrm{and} \mathrm{pretreated}$ with 400 or $880 \mathrm{mg} \mathrm{LC} / \mathrm{kg}$ fish/day for $21 \mathrm{~d}$. The values are expressed as mean $\pm \mathrm{sd}$ $(n=5)$. The significance levels observed are $* p<0.05$ or $* * * p<0.001$ in comparison to control group values, and $\& p<0.05$ or $\& \& \& p<0.001$ when $\mathrm{CYN}$-exposed fish are compared with or without LC pretreatment. 
Fig. 8. Cardiac fibers (A) and Capillaries (B) diameters $(\mu \mathrm{m})$ of Tilapia (Oreochromis niloticus) exposed to a single dose of $400 \mu \mathrm{g}$ pure CYN/kg fish bw or to lyophilized $A$. ovalisporum cells containing CYN (400 $\mu \mathrm{g}$ CYN/kg fish), and pretreated with 400 or $880 \mathrm{mg} \mathrm{LC} / \mathrm{kg}$ fish/day for $21 \mathrm{~d}$. The values are expressed as mean $\pm \operatorname{sd}(n=5)$. The significance levels observed are $\& p<0.05$ when CYN-exposed fish are compared with or without LC pretreatment. 

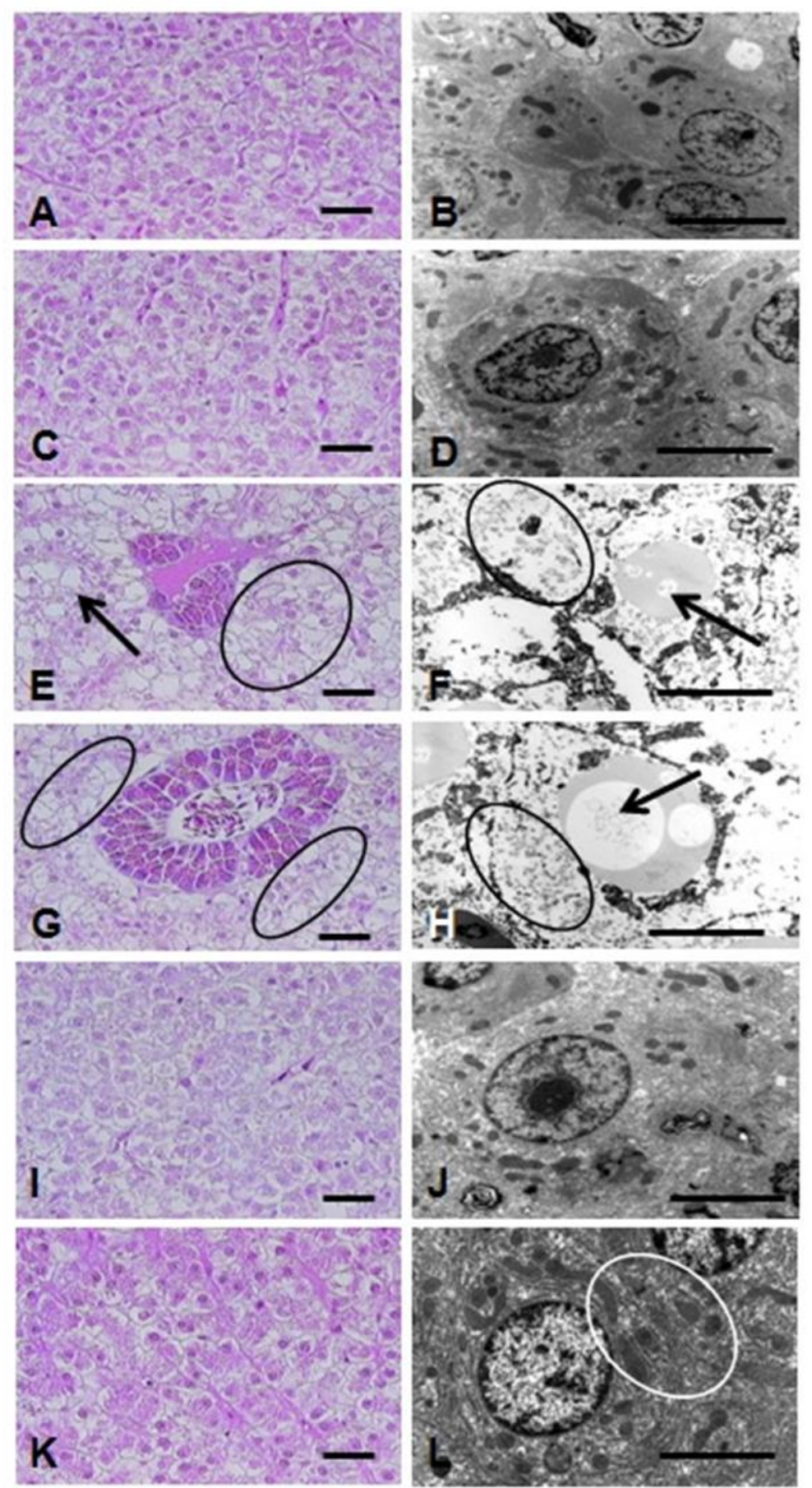

Figure 1 



Figure 2 

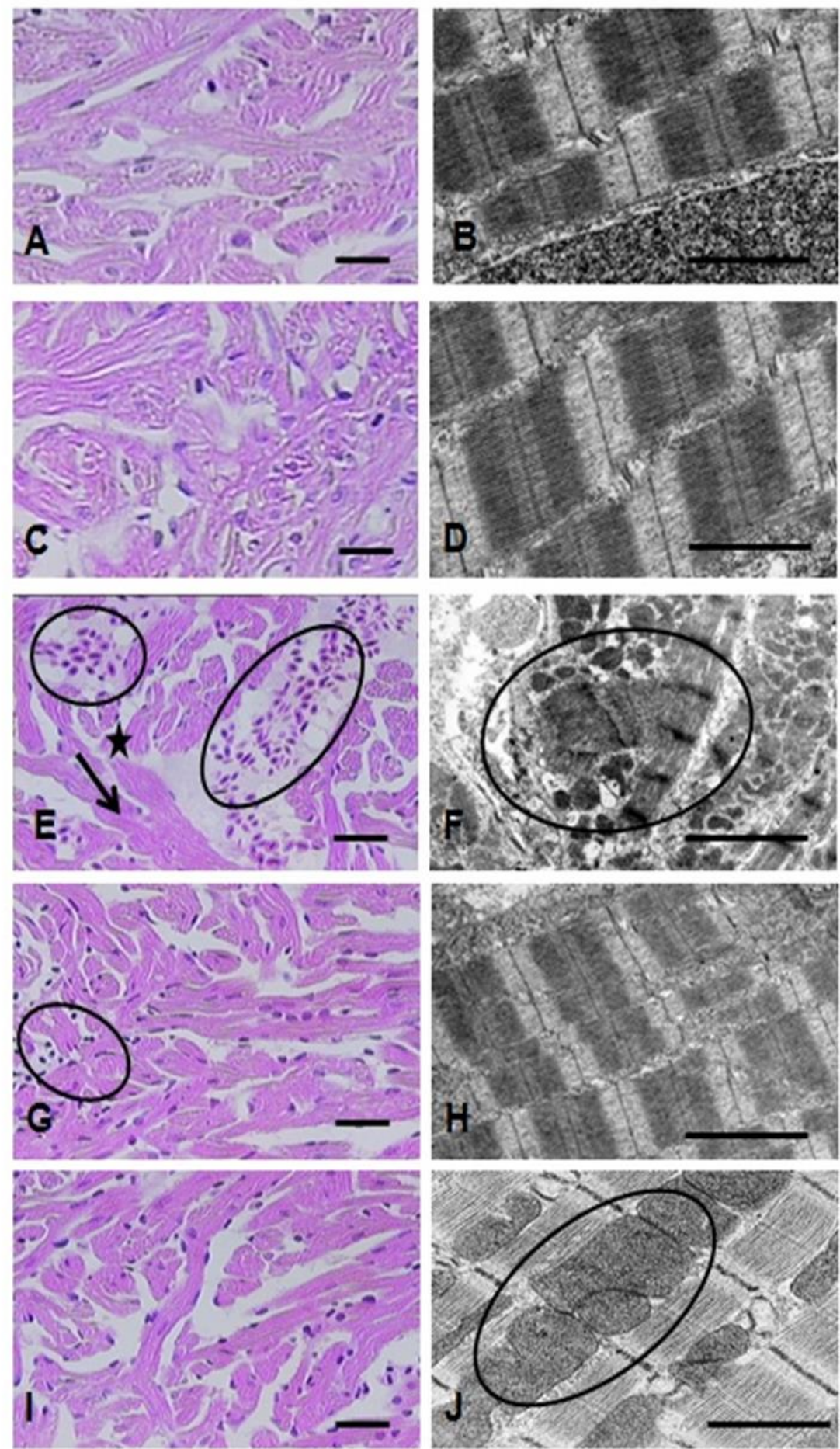

Figure 3 

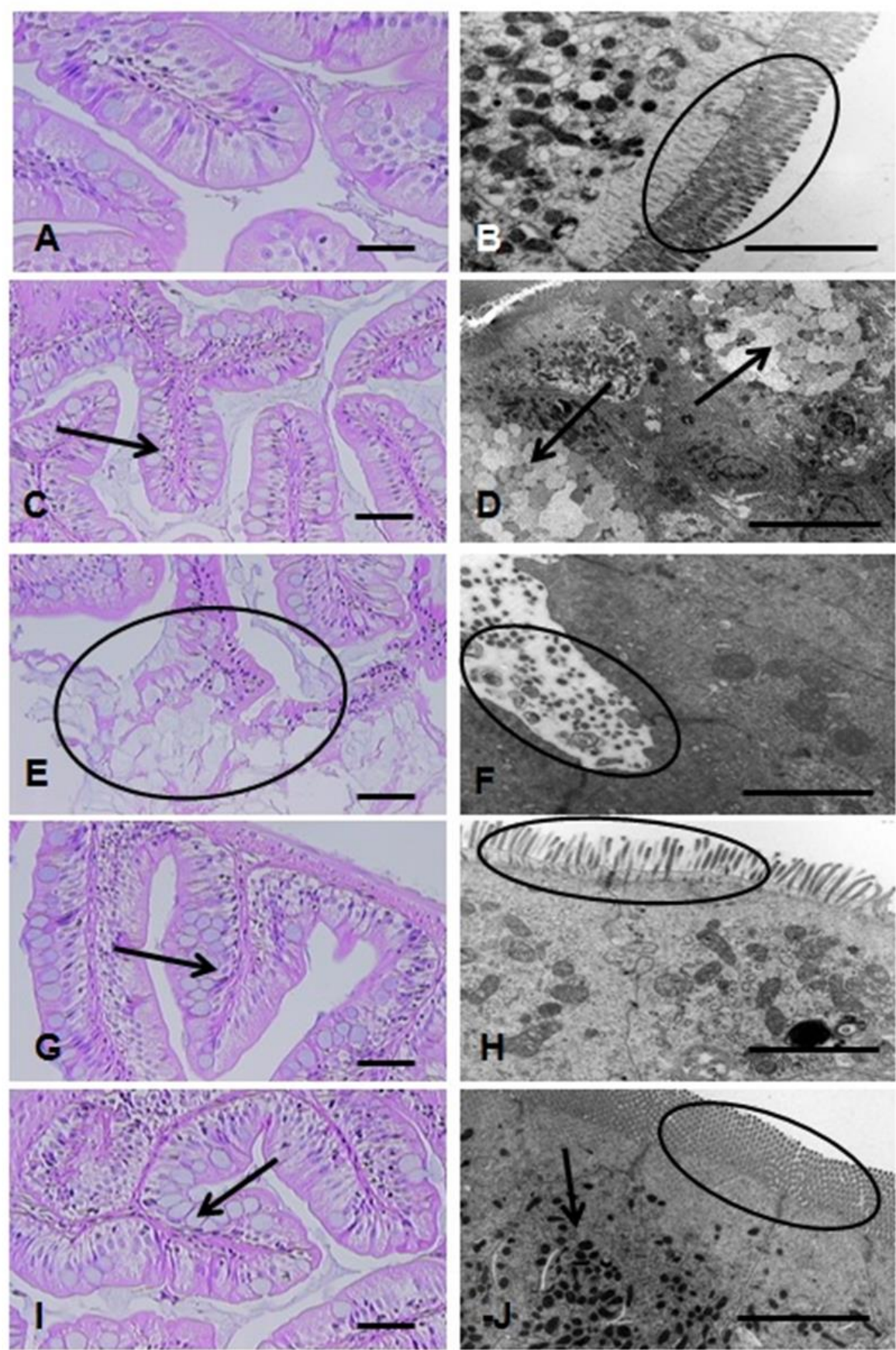

Figure 4 

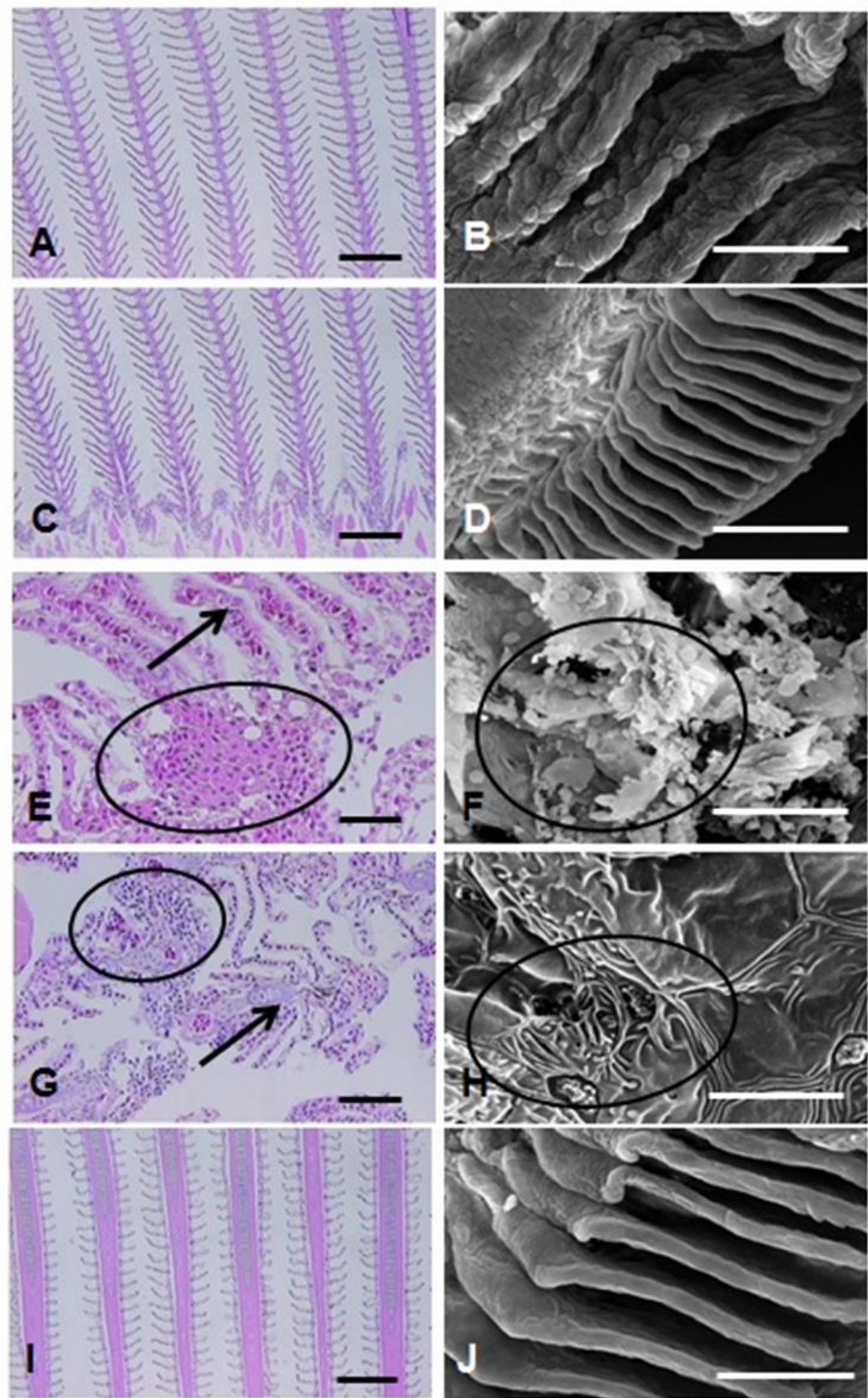

Figure 5 


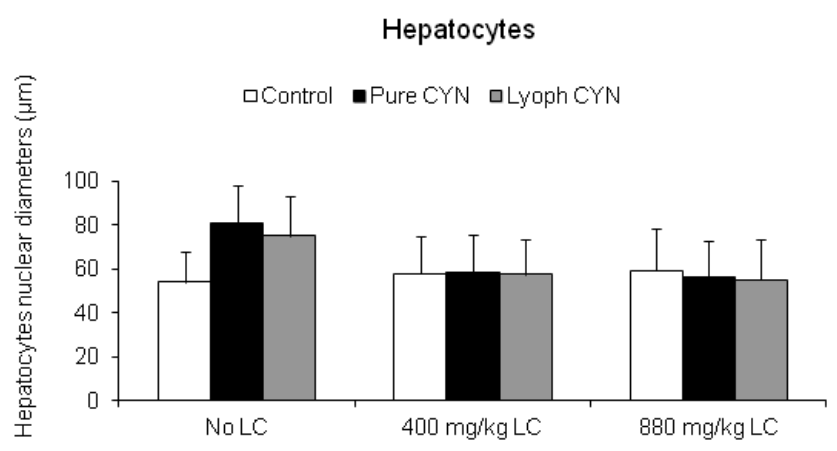

Figure 6

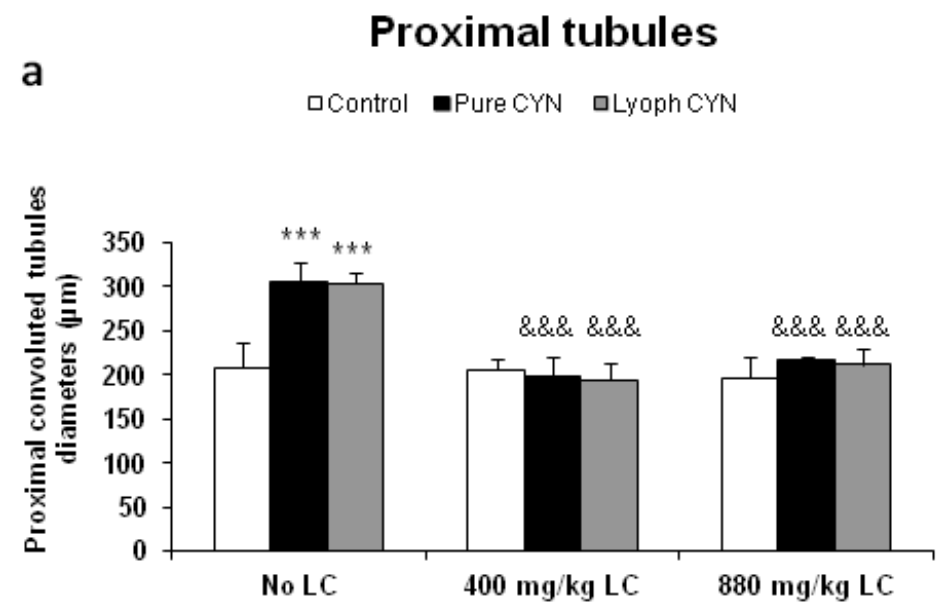

b

Distal tubules

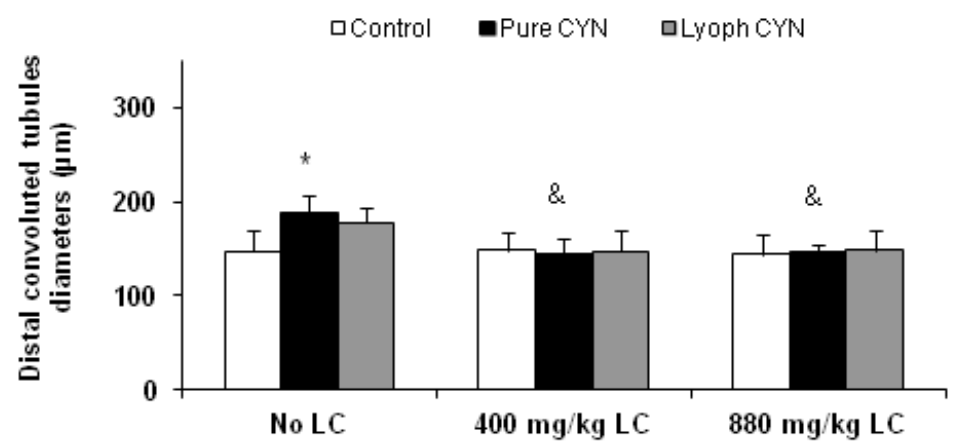

Figure 7 
a

\section{Cardiac fiber}

aControl aPure CYN aLyophCYN



b

\section{Capillaries}

aControl aPureCYN aLyophCYN

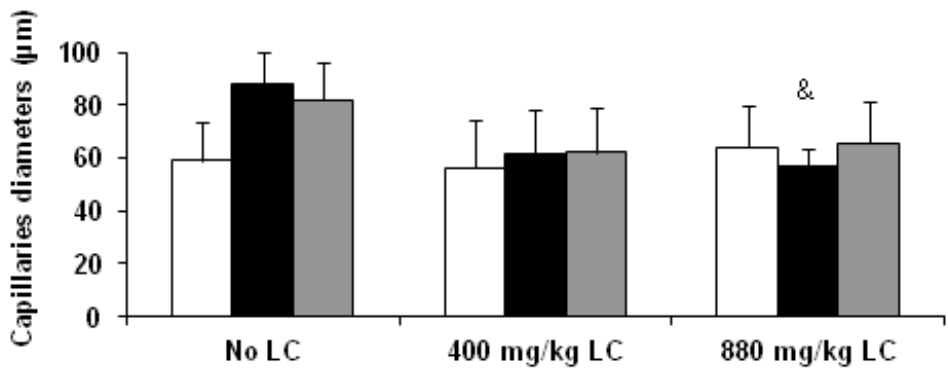

Figure 8 
Table 1. Feeding conditions $s^{\mathrm{a}}$ of $O$. niloticus and exposure conditions to Cylindrospermopsin (CYN). Numbers from 1 to 9 correspond with the aquaria where the different treatment conditions were carried out.

\begin{tabular}{|c|c|c|c|c|c|c|c|c|c|}
\hline Treatment & 1 & 2 & 3 & 4 & 5 & 6 & 7 & 8 & 9 \\
\hline Pure CYN & - & + & - & - & + & - & - & + & - \\
\hline Lyophilized cells with CYN and deoxy-CYN & - & - & + & - & - & + & - & - & + \\
\hline $400 \mathrm{mg} \mathrm{LC} / \mathrm{kg}$ bw fish/day (21 days) & - & - & - & + & + & + & - & - & - \\
\hline $880 \mathrm{mg} \mathrm{LC} / \mathrm{kg}$ bw fish/day (21 days) & - & - & - & - & - & - & + & + & + \\
\hline
\end{tabular}

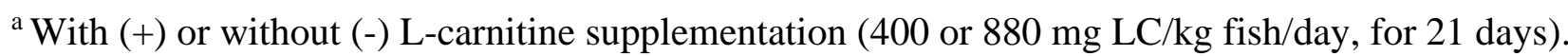

